\title{
Marcos Mercadante (1960-2011) and his legacy to Brazilian psychiatry
}

\section{Marcos Mercadante (1960-2011) e sua herança para a psiquiatria brasileira}

Soon after lunch on July 2, as I prepared to go visit him, I received a phone call from one of his best friends, Maria Conceição do Rosário (Ceiça), telling that he was no longer with us. One moment later it was Jair Mari, responsible for bringing him to the Universidade Federal de São Paulo (UNIFESP), who sent a text message that said: "We lost Markinhos".

Yes. On this day, Brazilian psychiatry, his friends, and especially his family lost one of their most loved and important members.

Victim of an incurable and lethal cancer, announced about a year earlier, Marcos Tomanik Mercadante struggled relentlessly until yielding to the natural course of his disease. Today, the sorrow for his absence is still poignant, but we can already remember his life story with pride.

Marcos chose a unique professional path that once revealed helps us to understand the great psychiatrist he came to be.

Soon after graduating from the Medical School of the Universidade de São Paulo (FMUSP) in 1983, Marcos went for a residency at the Enfance therapeutic community, headed by Oswaldo Dante Di Loretto, where he assisted children using principles focused on a social approach. Based on this experience, Markinhos advocated that medical residents in Child and Adolescent Psychiatry (CAP) should learn how to play with children and develop their creative capacity as a part of their semiotical apparatus. He viewed, thus, his profession as an art. With these fundaments, Marcos developed a special ability to interview and to treat his patients that involved a proportional emphasis on both the healthy aspects of their personalities and their illness.

Later, he came close to Stanislau Krinsky (according to Marcos, the first psychiatrist in CAP in Brazil) at the Faculdade de Ciências Médicas da Santa Casa, where he became chief of the Child Psychiatry Service (1989-1995). In the same period (1988-1993), he got his master's degree in clinical psychology from the Pontificia Universidade Católica de São Paulo, under the supervision of Marília Ancona Lopez.

I entered Marcos' professional history as his doctorate supervisor (1995-1999). After learning in depth about the role of social and psychological aspects in the origin of mental disorders, he wanted to conduct his doctoral studies based on the medical model. In the article that resulted from his thesis, published in the American Journal of Psychiatry ${ }^{1}$, he described for the first time the presence of tics and obsessive-compulsive disorder in rheumatic fever (without Sydenham's chorea). His work gave rise to a fertile line of research, later followed by Ana Hounie and Pedro Alvarenga. In that time and together with many other colleagues, like Roseli Shavitt and Ceiça, we created the Obsessive-Compulsive Spectrum Disorder Project (PROTOC), the Association of Families and Patients with Tourette's Syndrome, and the Association of ObsessiveCompulsive Disorder (ASTOC), besides organizing several events. We reached the end of this phase without knowing for sure who the supervisor was, since influences were reciprocal.

In 2000, Marcos went to Yale for his post-doctorate in order to learn the subtleties of the methodology of basic science ${ }^{2}$, having one of the most important CAP professors of current days as his supervisor: James Leckman.

He returned after two years with the purpose of creating a research program on developmental disorders. He worked as a professor at the Universidade Presbiteriana Mackenzie (20022007) until becoming an Associate Professor at UNIFESP's Department of Psychiatry. There, with Ceiça, he founded and directed the Child and Adolescent Psychiatry Unit (UPIA). In this unit, Marcos developed the most important Brazilian studies on autistic spectrum disorders ${ }^{3}$. He enjoyed himself writing articles as the one published in Medical Hypothesis ${ }^{4}$ where he speculates about how alterations in the neurogenesis of the amygdala could be implicated in certain forms of autism. Since his return from the USA, he read an article a day (as taught by Leckman) and found pleasure in raising hypotheses with an heuristic value on the nature of mental disorders.

Since 2003, with Luiz Rohde and myself, Marcos coordinated the National Institute of Developmental Psychiatry for Children and Adolescents (INPD) ${ }^{5}$. With us, Jair Mari, and Rodrigo Bressan, he was one of the editors of the Revista Brasileira de Psiquiatria and contributed for its great advances over the last decade.

His contributions for CAP would not be limited to the academic world. In 2010, with other important members of our society, Marcos created the association Autismo \& Realidade (Autism \& 
Reality), with parents and professionals dedicated to the search for and dissemination of knowledge concerning autism. In his recent endeavors, he showed great enthusiasm for a documentary on this topic, for which he had raised the funds. Even without time to complete this project, we shall soon have another form of remembering him thanks to his collaborators.

In conclusion: throughout his training, Marcos Mercadante sought to integrate different perspectives to understand the nature of mental disorders. He performed his work as an art and with a remarkable capacity to aggregate, having formed several groups.

In his personal life, Marcos made countless friends. From his first marriage, with psychologist Caia Pacifico, he had three beautiful children: Julia (an accomplished lawyer), Mariana (a dedicated medical student), and João Marcos (today in elementary school), who inherited his father's talent for clear reasoning and basketball. Magoo, thus nicknamed due to his resemblance with Mr. Magoo when he played wearing glasses, was one of the best players of all times in the basketball team of the Medical School of the Universidade de São Paulo.

More recently, Marcos lived with and married Claudia Bucalem, who stood restlessly by him up to his final moments. For his stepson Rodrigo, Marcos had his finest feelings.

Juarez Fagundes, one of his best friends, recollects that to Magoo everything seemed to be worthwhile. Adversities were never greater than the joys of each experience. And so it was until death came. Marcos struggled up to the last moment without anger or complaints. Over the last two months, although faced with the deterioration of his health, Marcos would talk about his plans for the future. One could inadvertently think that he was denying the nearness of his own death. To his friends, however, that was just him again, making everything around lighter, accepting his disease as a part of life, which must be lived softly.

Early on the day of the funeral, Juarez surprised everyone. He had spent the night painting the coffin in the most distinguished colors. Colorful as it was, it looked full of life. That could only be the coffin of our dear Markinhos, which shall now go on living inside us.

Euripedes Constantino Miguel Tenured Professor of the Department of Psychiatry of the Universidade de São Paulo Medical School

\section{References}

1. Mercadante MT, Busatto GF, Lombroso PJ,, Prado L, Rosário-Campos MC, do Valle R, Marques-Dias MJ, Kiss MH, Leckman JF, Miguel EC. The psychiatric symptoms of rheumatic fever . Am J Psychiatry. 2000;157(12):2036-8.

2. Morshed SA, Parveen S, Leckman JF, Mercadante MT, Bittencourt Kiss MH, Miguel EC, Arman A, Yazgan Y, Fujii T, Paul S, Peterson BS, Zhang H, King RA, Scahill L, Lombroso PJ. Antibodies against neural, nuclear, cytoskeletal, and streptococcal epitopes in children and adults with Tourette's syndrome, Sydenham's chorea, and autoimmune disorders. Biol Psychiatry. 2001;50(8):566-77.

3. Paula CS, Ribeiro SH, Fombonne E, Mercadante MT. Prevalence of pervasive developmental disorder in Brazil: A pilot study. J Autism Dev Disord. In press 2011.

4. Mercadante MT, Cysneiros RM, Schwartzman JS, Arida RM, Cavalheiro EA, Scorza FA. Neurogenesis in the amygdala: a new etiologic hypothesis of autism? Med Hypotheses. 2008;70(2):352-7.

5. Miguel EC, Mercadante MT, Grisi S, Rohde LA. The National Science and Technology Institute in Child and Adolescence Developmental Psychiatry: a new paradigm for Brazilian psychiatry focused on our children and their future. Rev Bras Psiquiatr. 2009;31(2):85-8. 